UDK: 341.018:347.772

347.772:341.018

Pregledni znanstveni rad

Primljen: 15. svibnja 2018.

Prof. dr. sc. Vesna KAZAZIĆ, Prihvaćen: 18. listopada 2018.

Pravni fakultet Sveučilišta u Mostaru

vesna.kazazic@sum.ba

Doc. dr. sc. Matej SAVIĆ,

Univerzitet u Banja Luci, Fakultet političkih nauka

matej.savic@fpn.unibl.org

\title{
AKTUALNA PITANJA MEĐUNARODNOPRAVNOG SUBJEKTIVITETA
}

Sažetak: U ovom radu autori se bave aktualnim teorijskim pitanjima međunarodnopravnoga subjektiviteta. Analiziraju se najznačajnija shvaćanja i koncepcije u teoriji međunarodnog prava, a koja imaju utjecaja na suvremene međunarodnopravne tendencije. Međunarodno pravo se mijenja, međunarodnopravni poredak, uz sve probleme, intenzivno se razvija, što direktno utječe na promjene u pogledu određenja subjekata međunarodnoga prava danas. Međunarodnopravni odnosi su izuzetno složeni i sve je više različitih - specifičnih nositelja prava $i$ obveza $u$ tim odnosima. Jedinke (organizmi, osobe) koje sudjeluju $u$ međunarodnopravnim odnosima sve više se (međusobno) razlikuju u pogledu statusa, obima subjektiviteta, opće i posebne legitimacije, konkretnih sposobnosti i sl. Teorija međunarodnoga prava danas nailazi na velike probleme u vezi sa određenjem subjekata međunarodnoga prava, što je jedno od osnovnih pitanja koja su razmatrana u ovome radu.

Ključne riječi: subjekti prava, međunarodnopravni subjektivitet, međunarodnopravni odnosi, voluntarizam, objektivizam, pravni pozitivizam, sposobnosti, prava i obveze.

\section{Prethodni pojam pravnog subjektiviteta}

Pitanje pravnog subjektiviteta, odnosno subjekata prava uopće izuzetno je složeno. U pravnoj terminologiji je uobičajeno da pojam osoba označava subjekta prava, odnosno organizam ili biće koje je sposobno da bude nositelj prava i obveza, neovisno od njegove svijesti 
i volje. ${ }^{1}$ Na prvom mjestu kao subjekti prava javljaju se ljudi, fizičke osobe, koji jednim dijelom prava i obveze stječu neovisno od svoje volje i svijesti, a drugim upravo realizacijom svoje volje. Pored fizičkih osoba, kao subjekti prava javljaju se i određene društvene tvorevine stvorene ljudskim udruživanjem radi ostvarivanja različitih interesa. Ove tvorevine se jednim imenom nazivaju pravnim osobama. Posebno mjesto među njima zauzima država kao subjekt međunarodnoga prava, koja istovjetno istupa i u pravnim odnosima domaćeg (unutarnjega) prava. ${ }^{2}$ To znači da "...ljudi i društvene tvorevine koje imaju pravne obveze i pravna ovlaštenja pravne ovlasti s obzirom na neke pravne objekte - tj. fizička i pravna lica” predstavljaju subjekte prava. ${ }^{3}$

Opća sposobnost subjekta jednog pravnog poretka koja podrazumijeva da on kao posebna jedinka (osoba - organizam, biće, entitet) aktivno sudjeluje u pravnim odnosima i da se u tim odnosima javlja kao nositelj prava i obveza određuje prirodu i obim njegovog pravnog subjektiviteta. Tako svi subjekti prava imaju pravnu sposobnost koja se praktično izjednačava sa pojmom subjekta prava i ona se ogleda u mogućnosti da određena osoba bude nositelj prava i obveza. Pored pravne sposobnosti, pravni subjektivitet se determinira uživanjem i poslovne sposobnosti. Ova sposobnost se može odrediti kao sposobnost da se svojim vlastitim izjavama volje preuzimaju obveze i realiziraju prava, tj. zasnivaju, mijenjaju i prekidaju pravni odnosi. ${ }^{4}$ U smislu pravnog subjektiviteta, pravnu i poslovnu sposobnost možemo odrediti kao opće sposobnosti subjekata prava. Pored njih, pravna teorija poznaje i posebne (dodatne) sposobnosti koje imaju značajnu ulogu posebno u pogledu određenja subjekata međunarodnoga prava, o čemu će kasnije biti više riječi.

Ako kažemo da subjekt nekog pravnog poretka predstavlja organizam, odnosno osobu koja ima određenu sposobnost u pravnim odnosima, naglasak stavljamo, kako logika nalaže, na određenu sposobnost, ali i na pravni odnos per se. Ako prihvatimo stanovište da je pravni odnos društveni odnos koji je reguliran pravom, sam po sebi nameće se zaključak da u ovom odnosu sudjeluju jedinke koje svoje aktivnosti ostvaruju u društvu uopće. Međutim, ovi organizmi, da bi se mogli definirati kao pravne osobe u pogledu svog statusa, prava i obveza, te subjektiviteta, moraju biti pravno formalizirani. A to znači da oni moraju ispuniti uvjete koje će im pravni poredak priznati, a kako bi mogli biti subjekti pravnih obveza i subjektivnih prava u određenom pravnom odnosu. Na ovaj način ovi organizmi objedinjuju pravnu i poslovnu sposobnost.

\footnotetext{
${ }^{1}$ SAVIĆ, S., Osnove prava, Banja Luka, 2005., str. 297.

2 Šire v. VRBAN, D., Država i pravo, Zagreb, 2003., str. 258.

${ }^{3}$ VISKOVIĆ, N., Teorija države i prava, Zagreb, 2001., str. 207.

${ }^{4}$ Ibid, str. 298.
} 
Sve gore navedeno se, svakako, odnosi i na subjekte međunarodnoga prava, odnosno međunarodnopravni subjektivitet uopće. Međutim, u pravnoj literaturi ne postoji potpuna suglasnost, kako o općem pojmu subjekata međunarodnog prava, tako i pri određivanju posebnih vrsta subjekata. Pojedini autori nastoje da pobliže odrede specifičnost subjekata $u$ oblasti međunarodnoga prava kako bi dešifrirali osnovne atribute međunarodnopravnoga subjektiviteta uopće. Međutim, pojam, pravnu prirodu i krajnje određenje međunarodnopravnoga subjektiviteta moramo promatrati, prije svega, kroz prizmu pravne doktrine i prakse koja je evoluirala kroz stoljeća uvjetujući shvaćanja o društvu, državi, subjektima prava, odnosu države i prava, kao i o konstelaciji između unutarnjega i međunarodnoga prava. Ovome moramo dodati i supstancijalnu, odnosno faktičku i političku dimenziju u okviru međunarodnopravnoga poretka, što je posebno značajno za određenje obima i kvaliteta međunarodnopravnoga subjektiviteta u suvremenim izazovima međunarodnoga prava.

\section{Teorijske koncepcije međunarodnopravnoga subjektiviteta}

\subsection{Teorijski pravci međunarodnoga prava}

U teoriji međunarodnoga prava postoji nemali broj shvaćanja o pojmu subjektiviteta koja pronalaze svoje utemeljenje u filozofskim školama i teorijama koje su se razvijale još od prirodno pravne škole. Sveobuhvatnost tih pogleda možemo raščlaniti na tri osnovna teorijska shvaćanja koja su uvjetovala današnji razvoj međunarodnopravne znanosti, te njima pridodati nedovoljno iskristalizirane nove ideje s kraja XX vijeka. To su, u najširem smislu: 1) voluntarističko shvaćanje 2) solidarističko i 3) objektivističko shvaćanje. Prve dvije teorije, iako dijametralno suprotne, imaju istovjetnu polaznu osnovu, ali i podrijetlo - obje su nastale $u$ okrilju pozitivističke pravne škole koja je sa svim svojim pravcima i teorijskim idejama i učenjima, bez dileme, najznačajnija za modernu pravnu znanost i njen daljnji razvoj; dok objektivizam predstavlja, naspram čistog pravnog pozitivizma - koji ulazi u ćorsokak pri pokušaju da razriješi fundamentalne probleme voluntarističkog shvaćanja - teorijsku postavku koja istovremeno prihvaća pozitivnopravne postulate, međutim, transcendira opće univerzalne vrijednosti, to jest aksiološki element međunarodnopravnog poretka postavljajući ga iznad tih postulata. ${ }^{5}$ Pored ovoga, pojedine kritičke teorijske konstrukcije novijeg datuma, kao što je

\footnotetext{
${ }^{5}$ Ipak, u kritici ovakvog shvaćanja se s pravom naglašava korelacija sa filozofskopravnom idejom univerzalizma koja na osebujan način definira univerzalnost pravnih normi, što je osporeno, posebno u pogledu pravne efikasnosti (obveznosti i primjene pravnih normi u međunarodnom pravu), ali i u pogledu podrijetla prava, odnosno osnove važenja ovako shvaćenih pravnih normi međunarodnoga prava. S druge strane ovo shvaćanje se kritički dovodi u
} 
postpozitivizam ili pak postmodernističko shvaćanje prava i pravnog poretka, još uvijek se nalaze u statusu ideja koje bi se (eventualno) mogle pravnoteorijski konstruirati tek u narednim godinama. Usprkos tomu što još uvijek nisu do kraja formirane kao cjelovite pravne teorije, ove ideje su izuzetno kontroverzne, pri čemu postmodernistički pravac u pravnoj znanosti, kako smatra S. Avramov, "predstavlja jednu nerealnu konstrukciju koja je više proizvod mašte, no do kraja izvedene analize stvarnog stanja". ${ }^{6}$ Iako u osnovi možemo prihvatiti da on ne odgovara stvarnom stanju, postmodernistička dekonstrukcija je u međunarodnome životu prisutna na razne načine. Poseban problem za pravnu znanost i teoriju međunarodnoga prava predstavlja činjenica da ova prisutnost otvara sve više pitanja i posredno stvara posljedice, pri čemu prolazi ispod perceptivnih i metodičkih radara međunarodnoga prava. ${ }^{7}$

Danas se svijet u cjelosti mijenja - mijenjaju se kvaliteti međunarodnoga života, i to se, na krilima globalizacije, događa izuzetnom brzinom. S tim u svezi, u doktrini međunarodnoga prava se često konstatiraju stare istine o potrebi da se međunarodno pravo mijenja ili treba da se mijenja. "Ali uporedo s tim, postoji i druga premisa koja upućuje na to da se sam svet menja. Ili, bliže, društvo i međunarodna zajednica preobražavaju pravo ili pak stvara se pravo da bi se uticalo na promenu društva i međunarodne zajednice." 8 Tako u teoriji međunarodnoga prava voluntarizam $^{9}$, odnosno konsenzualizam i pravni pozitivizam, početkom i tijekom XX stoljeća, ustupaju mjesto, istina teško, ograničenom i usmjerenom objektivizmu u međunarodnome pravu, koji se opet javlja u raznim fragmentiranim formama. ${ }^{10}$ Vrijednosti solidarizma su posljedično ostale iza Digijeve (Leon Duguit) ideje međunarodne solidarnosti, koja je opet na

svezu sa idealističkom teorijom u međunarodnim odnosima, i to sa njenim osnovama koje predstavljaju idealitet ove političke teorije.

${ }^{6}$ AVRAMOV, S., Postherojski rat zapada protiv Jugoslavije, Veternik, 1997., str. 77. Takođe, šire v. isto, str. 7378.

${ }^{7} \mathrm{O}$ ovome šire v. SAVIĆ, M., Međunarodno javno pravo i njegovi subjekti - neka od teorijskih određenja međunarodnopravnog subjektiviteta, Pravna riječ, god. X br. 37/2013., str. 162.

${ }^{8}$ Isto, 63, a šire v. WIEL, P., Le droit international en quete de son identite, Cours general de droit international public, Recueil des cours, 1992., VI 237, str. 27.

${ }^{9}$ Voluntarističko ili klasično shvaćanje, koje je gotovo dominiralo sve do XX stoljeća i prema kojemu su isključivo narodi (nacije), a kasnije države nositelji međunarodnopravnoga subjektiviteta, pronašlo je svoje aksiološke osnove u teoriji prirodnoga prava, da bi se kasnije u normativnom smislu potpuno ostvarilo kao dio pozitivnopravne škole prava. Voluntarizam je podrazumijevao da međunarodno pravo predstavlja pravo koje stvaraju suverene države inter se, pri čemu one posjeduju potpuni ekskluzivitet za primjenu, ili pak kršenje, tako shvaćenih međunarodnopravnih pravila. Takođe, voluntarizam, kako to sama riječ govori, naglašava jedinstveni kvalitet, odnosno suverenost vlasti država i njihovu volju kao jedinih subjekata međunarodnoga prava. Suverenost je, prema ovom shvaćanju, jedini kriterijum subjektiviteta u međunarodnome pravu. U modernim okolnostima međunarodnopravni voluntarizam korespondira sa realizmom u političkoj teoriji međunarodnih odnosa, posebno u pogledu ostvarenja vanjske politike i državnih interesa na međunarodnome planu. Šire v. SAVIĆ, M., ibid.

${ }^{10}$ Tako se u prvoj polovini XX stoljeća prepliću stanovišta realista (Jelinek, Heler, Lovelin i dr.), a koja slijede dualističke principe, konsenzualizam i prostu volju država (voluntarizam) i idealista (Kelzen, Lauterpaht, Radbruh, Tasić i dr.) koji u pravilu prihvaćaju monističke vrijednosti, objektivistički pristup, prirodna prava i ideal pravde $\mathrm{i}$ pravičnosti. Šire v. SAVIĆ, M., Međunarodno pravo na početku XXI vijeka - Teorijski pogled na savremenu doktrinu, procese i probleme međunarodnog pravnog poretka, Pravna riječ, br. 44/2015, god. XII. 
poseban način komplementarna (iako je u osnovi pogrešna) sa pravnim objektivizmom. ${ }^{11}$ Može se reći da se danas miješaju i idu usporedo dvije struje, voluntarizam i objektivizam "ustupajući jedna drugoj mjesto i preplićući se, zavisno od stavova pisaca, različitim ubeđenjem i tumačenjem interesa država u prvom redu." 12

Tako se poslije Drugog svjetskog rata pojavio trend koji je naglašavao analizu Politike moći (Power politics), pri čemu su se međunarodni odnosi razumijevali kroz mogućnost ostvarenja uticaja i dominacije. Međunarodno pravo je u okviru ovog pristupa predstavljeno samo kao rezultat političkih procesa i instrument za ostvarivanje interesa država. Glavni predstavnici ovakvog pristupa su H. Morgentau (H. Morgenthau), K. Tompson (K. Tompson), R. Aron (R. Aron) i dr. Ovakva shvaćanja, pored toga što su vodila općem pesimizmu, imaju velike nedostatke zato što počinju i završavaju sa unutardržavnim aktivnostima - realizacija vanjske politike, što ne samo da nije dovoljna platforma za shvaćanje međunarodnoga prava, nego je i pogrešna. Ovo je možda najistaknutiji moderni oblik voluntarizma u XX stoljeću. S druge strane, tzv. teorija pravde (Theory of Justice) prema kojoj je međunarodno pravo shvaćeno kao otjelotvorenje prirodnoga prava, razvila se u vrijeme uspostavljanja međunarodnih organizacija i novonastalih problema $u$ pogledu međunarodne pravde. Predstavnici ove teorije, kao što su Dž. Rols (J. Rawls), A. D'Amato (A. D’Amato) i H. Lauterpaht (H. Lauterpacht) naglašavali su neophodnost prirodnog prava i značaj etičkih standarda u pravnome poretku, kao što su neagresivno postojanje i ljudska prava.

Partikularno tumačenje interesa država, to jest analiza državne participacije $u$ međunarodnim odnosima, te ugradnja načina, obrazaca, artikulacije i sl. u postupanju i ponašanju država i njihovih predstavnika u međunarodnome životu, omogućila je nove metodičke pristupe u međunarodnomu pravu. Ovo je naizgled omogućilo lepezu novih, alternativnih teza, međutim, samo je produbilo i osuvremenilo voluntaristička shvaćanja i

\footnotetext{
${ }^{11}$ Tvorac ove teorije je francuski teoretičar prava L. Digi koji je došao do zaključka da se svim ljudima nameće jedan društveni zakon koji nije metafizičke prirode, već je proizvod svjesne aktivnosti ljudi. Temelj ovog društvenog zakona je originarna društvena norma, koja se (univerzalno) odnosi na sve ljude. Ovdje već možemo uvidjeti problem koji se manifestirao jer je ova teza bila u koliziji, s jedne strane, sa postulatima prirodnoga prava koje su preferirali idealisti toga vremena u Francuskoj, pri čemu je, s druge strane, opovrgavala gotovo sve principe pozitivističke pravne škole. Naime, teza o postojanju jedinstvenoga društvenog zakona koji je, prema Digiju, univerzalan negira postojanje prirodnog prava kao korpusa fundamentalnih prav(il)a, na osnovu čega pravo gubi sve osnove metafizičkog. Međutim, ono na ovaj način gubi i materijalnopravnu supstanciju jer se manifestira kao skup društvenih pravila koja stvaraju ljudi. Pravo se vezuje za društvo i, prema Digiju, nastaje samo kroz svjesnu kolektivnu aktivnost ljudi. Naime, društvena norma je jedna, jedinstvena po svom osnovu, karakteru i predmetu, razlika postoji samo u intenzitetu društvene reakcije koju izaziva njeno kršenje u različitim periodima i državama. Taj Digijev sociologizam je uveliko kritiziran od gotovo svih pravnih pisaca koji su predstavljali idealizam toga doba. Međutim, ovakav pristup, mada metodički drugačije postavljen, i danas se među nekim pravnim praktičarima i političkim teoretičarima prihvaća i konceptualno razmatra. Šire v. SAVIĆ, M., ibid.

${ }^{12}$ ĐORĐEVIĆ, S., Uvod u međunarodno pravo, Beograd, 2007., str. 64.
} 
probleme. Na ovaj način je došlo je do implementiranja bihejviorističkog shvaćanja (teorije) međunarodnih odnosa u teoriju međunarodnog prava od strane velikog broja anglosaksonskih pisaca. ${ }^{13}$ Popularno nazvan kao Sljedeći talas napretka ${ }^{14}$ ovaj politički orijentiran koncept određuje pravo kao sveobuhvatni proces donošenja odluka zanemarujući smisao prava i usklađenost pravnih pravila i obveza. Kako je to naglasio M. S. Mekdugl (M. S. McDougal), "to je aktivan sveprihvatajući pristup koji promatra međunarodno pravo kao dinamičan sustav koji funkcionira u okviru posebnog tipa svjetskog poretka." ${ }^{15}$ Iako se na prvi pogled može činiti drugačije, bihejviorizam, kao koncept u međunarodnome pravu, predstavlja samo široku lepezu metoda ${ }^{16}$ koje u empirijskom (danas i u aksiološkom) smislu predstavljaju osnovu novog voluntarizma pojedinih država. Ovaj koncept je s razlogom kritiziran od strane modernih, ali i tradicionalnih pravnih pisaca, zato što pogrešno tumači pravnu prirodu međunarodnoga prava i ignorira činjenicu da su "nacije (države op. aut.) te koje su prihvatile međunarodno pravo takvo kakvo jest i da one prihvaćaju njegove naredbe" 17 iako već odavno nisu njegovi jedini subjekti. To državno prihvaćanje međunarodnoga prava je udarilo prvi temelj općem međunarodnom pravu - ius cogens. Na osnovu tog temelja danas je gotovo potpuno izgrađen sustav objektivnih normi međunarodnoga prava, a koji predstavlja prvi stub suvremenog međunarodnopravnog poretka.

S druge strane, tzv. kritičke pravne studije - Critical Legal Studies, ${ }^{18}$ novijeg datuma, pokušavaju situaciju promatrati drugačije, više kroz perspektivu širenja horizonta međunarodnopravnog poretka, naspram bihejviorističkog koncepta, prema kojemu nacionalne države prihvaćaju obveze i određena definirana ograničenja u svom postupanju. ${ }^{19}$ Ovaj teorijski pravac "naglašava da je tradicionalni pristup međunarodnome pravu u osnovi transponirao liberalne principe domicilnih sustava na međunarodni plan, što je dovelo do novih problema" ${ }^{20}$ Drugim riječima, "liberalizam konstantno pokušava napraviti balans između individualnih sloboda i društvenog poretka i kao takav je osporen, neizbježno zauzimajući stranu jednim ili

\footnotetext{
${ }^{13}$ To su kako navodi M. Šo (Malcolm N. Shaw), K. A. Mekliland (C. A. McClelland), M. A. Kaplan (M. A Kaplan), R. A. Falk (R. A. Falk) i drugi. Bihejvioralizam je podijelio oblast međunarodnih odnosa na dva učenja. Prvo koje razmatra tehnike vanjske politike i drugo koje materiji međunarodnih odnosa pristupa kroz analizu međunarodnoga sustava. Šire v. SHAW, M. N., International Law, VII Edition, Cambridge University Press, 2014., str. 40.

${ }^{14}$ Engl. Next Wave of Advance.

${ }^{15}$ Šre v. McDOUGAL, M. S., International Law, Power and Policy, Hague Recueil, 1952., str. 195.

${ }^{16}$ Ibid.

17 Šire v. HIGGINS, R., Policy Considerations and The International Judical Process, ICLQ 17, 1986., str. 58.

${ }^{18}$ Kritičke pravne studije su u zemljama političkog zapada popularno nazvane terminom Novi pristupi međunarodnome pravu, New Approaches to International Law (NAIL) čime je, kako suštinski, tako i formalno proširen okvir u pogledu teorijskih istraživanja.

${ }^{19}$ SHAW, M. N., cit. dj. str. 41.

${ }^{20}$ KOSKENNIEMI, M. A., The Politics of International Law, Oxford University Press, 2011., str. 16.
} 
drugim propozicijama, što je pogrešno. Postoje samo dvije mogućnosti u pogledu pravde kao takve - subjektivno, samo po sebi, ili nametnuto (objektivno op. aut.)." ${ }^{21}$ Ovo u određenoj mjeri korespondira sa stavom teoretičara radikalnog liberalizma - libertarijancima. ${ }^{22}$ Teoretičari kritičke pravne studije naglašavaju da moć države i međunarodni pravni koncept moraju biti uzeti u obzir kao što pravni okvir odražava politički faktor. ${ }^{23}$ Tako M. A. Koskenijemi (M. A. Koskenniemi) naglašava da "postrealistička teorija pokušava razriješiti pitanje odnosa prava i društva, kao i ograničenja legitimnosti u svijetu suverena kao svijetu jednog problema koncepta moći." ${ }^{24}$ Rezultat je takav da je u okviru kritičke pravne studije predložen koncept prema kojemu ne postoji koherentan međunarodni sustav na osnovu kojeg bi se postojeći poredak morao koncentrirati na ad hoc pravne procese, i to one koji odražavaju stvarno stanje stvari u smislu koncentriranja moći. Zapravo, riječ je o pokušaju da se volja država na jedan pragmatičan i nadasve analitički način segmentira i determinira u odnosu na međunarodni poredak. Postrealizam je sam po sebi, gotovo u svim oblicima, pogrešan jer predstavlja iskonski oblik voluntarizma prilagođen suvremenom međunarodnome životu. Na taj, danas, sofisticiran način samo se vraćamo na početak. Pravimo iste greške uprkos beskraju objavljenih knjiga koje osuđuju takav primitivan pristup međunarodnome životu, a koji se ogleda kroz prosti voluntarizam u međunarodnome pravu. ${ }^{25}$

Gore navedeni pregled obuhvaća teorijska shvaćanja i praktične koncepcije, pravnopolitičke paradigme, teze $\mathrm{i}$ ideje u teoriji međunarodnog prava (i politčkoj teoriji međunarodnih odnosa), a koje se, prije svega, bave fundamentalnim pitanjima prirode i suštine međunarodnopravnoga poretka. Samim tim što sve ove znanstvene kategorije naglasak stavljaju

\footnotetext{
${ }^{21}$ Šire v. KOSKENNIEMI, M. A., From Apology to Utopia, Helsinki 1989., str. 214.

${ }^{22}$ Popularno nazvani Libertarijanci propagiraju kranji antietatizam i, što je za nas posebno značajno, maksimalnu pravnu deregulaciju (sa hipotezom samoregulacije) u kojoj su osnovne vrijednosti individualno pravo vlasništva i „totalna“ sloboda. Kako to navodi A. Savanović, „Ono što je prvi rezultat političkog uspona libertarijanizma, a s njim i anarhokapitalizma, i korak već poduzet u mnogim zemljama, jeste redukovanje sa jedne strane socijalne države i bilo kakvih drugih netržišnih humanizama, a s druge strane nacionalne države." Šire v. A. Savanović, Anarhokapitalizam, politička filozofija antidržavnog kapitalizma, Banja Luka 2011., str. 15.

${ }^{23}$ MACDONALD, R. St J. i JOHNSTON, D., The Structure and Processes of International Law, Dordrecht, 1983. kao i MARKS, S., The Riddle of All Constitutions: International Law, Democracy and the Critique of Ideology, Cambridge University Press, 2000., str. 190-211.

${ }^{24}$ KOSKENNIEMI, M. A., cit. dj. str. 21.

${ }^{25}$ Međunarodnopravni voluntarizam je omogućio uspostavljanje osnovnih normi međunarodnog prava. Na osnovu ovog koncepta utemeljeno je i međunarodno pravo u klasičnom smislu. Vrijednosti međunarodnopravnoga voluntarizma predstavljaju stabilnu osnovu za objektivističku izgradnju međunarodnopravnog poretka. Međutim, posebno danas prosti voluntarizam (tj. prihvatanje proste volje kao osnovnog postulata) u međunarodnopravnome poretku, ne samo da je pogrešan, već je i destruktivan, jer podrazumijeva uzdizanje političke volje na prvo mjesto, što opet uvjetuje potpunu dominaciju političke moći na međunarodnome planu. Prihvatanje teorijskih koncepcija koje preferiraju voluntarizam u suvremenom obliku udaljava nas od prava, a približava nas politici (točnije suvremenom obliku realpolitike). Na ovaj način, međunarodni procesi bi se kretali u pravcu sve većeg kršenja (zaobilaženja) međunarodnog prava i stvaranja velikog broja tzv. hibridnih konflikata. Sve ovo se na različite načine, zapravo danas, i dešava u međunarodnome životu.
} 
na esenciju prava uopće - podrijetlo i osnovu prava, stvaranje prava, obaveznost prava, osnovni princip pravde da svakome treba dati ono što mu pripada ${ }^{26}$, progresivni razvoj prava, primjenu pravnih normi itd. - što se kumulativno odnosi i na međunarodno pravo i međunarodnopravni poredak, one determiniraju i teorijskopravne koncepcije shvaćanja međunarodnopravnoga subjektiviteta. U prilog ovome treba istaći da teorijsko određenje subjekata međunarodnoga prava predstavlja još jedan, pored podrijetla i osnove prava, vrlo važan fundament pravne znanosti, a implicite i teorije međunarodnoga prava.

\subsection{Koncepti međunarodnopravnog subjektiviteta}

Ne postoji sumnja da subjektivitet u međunarodnome pravu postoji - pravne osobe, njegovi subjekti su osnova te postojanosti. Međutim, intenzitet međunarodnopravnih odnosa i međunarodne politike uvjetovao je niz različitih koncepcija u pogledu definiranja međunarodnopravnoga subjektiviteta (suštine, osnove, prirode, pravnog okvira, kvaliteta i dr.)

U teoriji međunarodnog prava možemo izdvojiti pet osnovnih konceptualnih postavki međunarodnopravnoga subjektiviteta koje predstavljaju doktrinarni okvir (prema kojemu danas možemo odrediti, ali i artikulirati) međunarodnopravnoga subjektiviteta uopće. ${ }^{27}$

a) Na prvom mjestu to je koncept koji daje ekskluzivni subjektivitet državama u međunarodnome pravu. Ovu teorijsku pretpostavku R. Portman (R. Portmann) definira kao States-only concept. ${ }^{28}$ Ovaj koncept odgovara klasičnom međunarodnome pravu i korespondira sa voluntarističkom teorijom međunarodnoga prava. Prema ovom konceptu, postoji samo jedan uvjet za stjecanje međunarodnopravnoga subjektiviteta koji podrazumijeva potpunu državnost, odnosno suverenost državne vlasti prema vani, tzv. vanjsku suverenost države. Vanjski suverenitet kao ekskluzivitet temelji se na principu suverene jednakosti - načela ius imperii, koji se u mnogočemu razlikuje od suvremenog načela suverene jednakosti, odnosno suverene neovisnosti. ${ }^{29}$

\footnotetext{
${ }^{26}$ Šire v. SAVIĆ, S., Pojam normativnog poretka, prilog kritici Kelzenove normativne doktrine, Banja Luka, 1995., str. 143.

${ }^{27}$ O ovome, šire v. PORTMANN, R., Legal Personality in International Law, Cambridge University Press, 2010., SHAW, M. N., International Law, Cambridge University Press, 2014., NIJMAN, J. E., The Concept of International Legal Personality, The Hague, 2004.

${ }^{28}$ PORTMANN, R., cit., dj. str. 13.

${ }^{29}$ Šire v. SAVIĆ, M., Suverenost, nevazisnost $i$ jednakost u kontekstu osnovnih prava (i dužnosti) država u savremenim izazovima međunarodnog prava, Godišnjak Pravnog fakulteta u Banjaluci, god. XXXVII br. 37. 2015.
} 
b) Zatim postoji koncept (općeg) priznanja - Recognition concept, koji podrazumijeva da su države originarni subjekti međunarodnoga prava i da pored njih drugi organizmi ipak mogu steći međunarodnopravni subjektivitet, ali pod posebnim uvjetima. Ovi organizmi se, prema ovoj koncepciji, često nazivaju derivativni subjekti međunarodnoga prava, što se posebno odnosi na međunarodne organizacije. Ovaj koncept podrazumijeva eksplicitno ili implicitno međunarodno priznanje nekog organizma (kao subjekta) od strane država. ${ }^{30}$ Prava i dužnosti ovih subjekata su ograničena, prvo voljom država, a zatim i kriterijumima koje države (ekskluzivno) određuju i ispunjavaju. Ovaj koncept stoji u neposrednoj svezi sa konstitutivnom teorijom priznanja u međunarodnopravnome poretku koja je danas, kako doktrinarno, tako i praktično oborena.

v) Sljedeća je individualistička koncepcija - Individualistic Concept, koja podrazumijeva pretpostavku pojedinačnog međunarodnopravnoga subjektiviteta koji predodređuje postojanje osnovnih normi međunarodnoga prava. Individualizam korespondira sa solidarističkim shvatanjem međunarodnoga prava. Prema ovom konceptu, države i drugi organizmi u međunarodnome pravu mogu objediniti međunarodnopravni subjektitvitet samo pod pretpostavkom da se osnovne norme međunarodnoga prava neposredno na njih odnose. To znači da ove jedinke moraju biti individualno prepoznate od strane međunarodnopravnoga poretka, što per se uvjetuje partikulaciju među organizmima koji sudjeluju u međunarodnopravnim odnosima. Ovaj koncept istovremeno stavlja naglasak na međunarodnopravnu odgovornost ${ }^{31}$, što opet otvara niz teorijskih problema u smislu odnosa javnoga i privatnoga prava.

g) Četvrti koncept je formalnopravni - Formal concept, i on definira međunarodno pravo kao otvoren poredak u kojemu nema posebnih pretpostavki prema kojima se može odrediti tko jeste, a tko nije pravna osoba. Zapravo, ovaj koncept odbacuje tradicionalni pojam međunarodnopravnoga subjektiviteta. Posebni kvaliteti (suverenosti) koji uvjetuju postojanje pravne osobe u međunarodnome pravu postaju stvar prošlosti jer pravna osoba, prema ovom konceptu, više ne postoji u originarnom smislu te riječi. Njeno mjesto mogu zauzeti svi oni organizmi, entiteti, jedinke koje su u mogućnosti da budu adresati općeg međunarodnoga prava (ius cogens). Pravna osoba,

\footnotetext{
30 Ibid.

${ }^{31}$ PORTMANN, R., cit. dj. str. 14.
} 
ovako shvaćena, uspostavlja se stjecanjem općih, ali i posebnih sposobnosti koje su na ovaj način izuzetno značajne u međunarodnopravnim odnosima.

d) Nadalje, možemo primijetiti i koncept sudionika - Actors concept, koji potpuno odbacuje prethodna shvaćanja međunarodnopravnoga subjektiviteta i sam koncept pravne osobe. U tom smislu, ovaj koncept prihvaća pretpostavku da su svi sudionici međunarodnih odnosa relevantni u pogledu međunarodnopravnoga subjektiviteta, shodno svom značaju, utjecaju i aktivnostima. U međunarodnomepravu, na ovaj način, više nema subjekata i objekata, postoje samo sudionici međunarodnopravnih odnosa. Prema ovome, određeni sudionici posjeduju konkretna prava i dužnosti, što uvjetuje procese donošenja odluka u kojima sudionici pojedinačno participiraju, u zavisnosti od njihove efektivne (političke) moći. ${ }^{32}$ Ovaj koncept posredno odgovara suvremenom voluntarizmu i ideji politike moći (Power Politics), što nas vraća na početak - u voluntarizam.

\section{Suvremeni izazovi međunarodnopravnoga subjektiviteta}

Međunarodnopravni subjektivitet je po mnogočemu specifičan, što je svakako uvjetovano prirodom međunarodnoga prava koje se znatno razlikuje od normativnog poretka koji se stvara i primjenjuje u unutarnjem (državnom) pravu. To je posljedica činjenice da međunarodno pravo uređuje odnose koji se odvijaju na međunarodnoj sceni i oni se razlikuju od onoga što se dešava unutar državnih granica. ${ }^{33}$ Subjektivitet u međunarodnome pravu zahtijeva posebno razmatranje međusobnog odnosa između prava i dužnosti (obveza) koje su određene u međunarodnopravnom poretku, kao i definiranje sposobnosti pravnih subjekata i kapaciteta za sprovođenje konkretnih zahtijeva u međunarodnopravnim odnosima. Kako to naglašava M. Šo (M. N. Shaw) "u unutarnjem pravu pojedinci, ograničene kompanije i javna poduzeća su prepoznati kao posebne pravne osobe, u uvjetima koji su uokvireni relevantnom legislaturom. Pravo je to koje određuje okvir i prirodu pravne osobe (ličnosti)." 34 Tako i međunarodno pravo na specifične načine određuje okvir i prirodu ličnosti kojima određuje međunarodnopravni subjektivitet.

\footnotetext{
32 Ibid.

${ }^{33}$ KRIVOKAPIĆ, B., Aktuelni problemi međunarodnog prava, Beograd, 2011., str. 68.

${ }^{34}$ SHAW, M. N., cit. dj. str. 142.
} 
U skladu sa navedenim, subjektivitet $\mathrm{u}$ međunarodnom pravu, pored prethodno definiranih općih sposobnosti, mora biti dopunjen prvo širokim okvirom posebnih sposobnosti, a zatim i faktičkom, odnosno društvenom (preciznije, političkom) dimenzijom koja posredno utječe na formiranje, priznanje i postojanje pravnih subjekata, bilo da oni egzistiraju istovremeno $\mathrm{u}$ unutarnjem (državnom) $\mathrm{i}$ međunarodnom ili, pak, samo $\mathrm{u}$ međunarodnopravnome poretku. Ovo je jedini način na koji možemo u cjelosti obuhvatiti i odrediti prirodu, formu i obim subjekata međunarodnoga prava. Istina, ovaj supstancijalni segment ima mnogo manje značaja unutar određene države, naprosto zbog prirode njenog pravnog poretka koji je hijerarhijski precizno definiran i formalno, prema načelu zakonitosti, ustrojen. Iz tog razloga se pri teorijskopravnom određenju subjekata (državnog) prava i ne uzima u obzir.

S druge strane, u međunarodnopravnome poretku koji ne poznaje hijerarhiju pravnih akata, njegova faktička komponenta ima mnogo veću ulogu u smislu determiniranja pravnog odnosa a priori lege, a zatim i u pogledu priznavanja ili nepriznavanja konkretnih sposobnosti određenim organizmima. Ovo znači da međunarodnopravni subjektivitet objedinjuje participaciju uz određeni oblik prihvaćanja od strane zajednice. Ove dvije apstraktno postavljene kategorije predstavljaju esenciju složenosti subjektiviteta u međunarodnome pravu. Naprosto, međunarodno pravo ne poznaje ius imperii u onom smislu u kojem država temelji poredak vlasti i stupa u javnopravne odnose. Participacija podrazumijeva sposobnost stupanja u međunarodnopravne odnose i tako objedinjuje pravnu i poslovnu sposobnost subjekata, dok prihvaćanje s druge strane podrazumijeva određenu vrstu legitimacije unutar međunarodne zajednice. Međunarodno pravo i jeste na prvom mjestu javno pravo jer je unutar međunarodnopravnoga poretka ius imperii princip, načelo, odnosno pravo na osnovu kojeg se države među sebi formalno jednakim subjektima legitimiraju i tako tvore međunarodnu zajednicu.

Konkretna jednačina čisto etatistički uokvirena predstavlja tekovinu klasičnog međunarodnoga (međudržavnog) prava $^{35}$ i mogla je biti važeća sve dok koordinacija između

\footnotetext{
${ }^{35} \mathrm{U}$ analizi položaja međunarodnoga prava na početku XXI stoljeća može se reći da smo, kako to naglašava $S$. Đorđević, ,Za posljednja dva veka prošli put od klasičnog međunarodnog prava od kraja XIX veka do početka XX veka, savremenog međunarodnog prava kroz XX vek i nagoveštaja novog svetskog poretka prema XXI veku“ pri čemu se postavlja pitanje sadržine i ostvarljivosti takvog novog svjetskoga poretka. Šre v. S. Đorđević, cit. dj. str. 66. Međutim, mišljenja smo da bi period od posljednjih godina XIX do kraja XX stoljeća bilo preciznije odrediti kao epohu modernog međunarodnoga prava, a koja je uslijedila sa prvim sustavnim dokumentima i međunarodnim organizacijama nakon klasičnog doba. S druge strane, kraj XX stoljeća i vrijeme u kojemu živimo politički zapad uistinu jeste odredio terminom Novi svjetski poredak (New World Order). Ipak, međunarodni život se do danas nije baš razvijao u skladu sa njegovim vrijednostima. Dobili smo niz alternativnih pravaca, multipolarizaciju, formirane su posebne međunarodne institucije i asocijacije npr. BRICS itd. Ovo je kompromitiralo ideju Novog
} 
tako shvaćenih subjekata nije prvo utjelotvorila međunarodne organizacije kao institucionalni okvir suradnje, a zatim i transnacionalne aktere u međunarodnome životu. Ako uzmemo u obzir i fenomen globalizacije koji je, prije svega, u oblasti komunikacije i privatnom području poništio granice, možemo primijetiti da postoji neophodnost za, ako ne stvaranje nove, onda za nadogradnjom ove voluntaristički i pravnopozitivistički postavljene formule. Ovo, prije svega, pomjera granice u pogledu shvaćanja međunarodnopravnoga poretka uopće, što naravno uvjetuje i određenje međunarodnopravnoga subjektiviteta - prihvaćanje ili odbacivanje egzistencije pravne osobe, jedinki koje na raznolike načine sudjeluju u pravnim odnosima $\mathrm{u}$ međunarodnome životu. Pitanje je prosto, a suština izuzetno složena, jer se na ovom mjestu otvara problem kriterijuma prema kojem se može utvrditi postojanje ili pak nepostojanje međunarodnopravnoga subjektiviteta određenih organizama.

Međutim, danas u međunarodnopravnim odnosima participiraju i subjekti koji ne funkcioniraju prema načelu jednakosti. Pored ovoga, značenje pojma međunarodne zajednice nije istovjetno kao što je nekad bilo. Suvremeni međunarodni tokovi donijeli su množenje odnosa, kao i posebnih sposobnosti različitih subjekata koji stupaju u te odnose, ali su omogućili i dekompoziciju u pogledu priznanja i samog značenja pojma međunarodne zajednice. Rezultat ovoga je takav da međunarodno pravo danas poznaje i subjekte koji nisu na ovaj način jednaki - oni su posebno legitimirani, konstituiraju se i funkcioniraju prema specialis utvrđenim uvjetima. Oni zauzimaju posebno mjesto u međunarodnopravnim odnosima i preuzimaju specifična prava i obveze, što otvara nove dileme u vezi sa međunarodnopravnim subjektivitetom uopće. Ipak, s jedne strane ne mogu biti svi politički akteri identificirani kao subjekti međunarodnoga prava, a s druge, mnogi od njih imaju veći (neformalni) utjecaj na njega od većine međunarodnopriznatih država i postojećih međunarodnih organizacija. U pogledu navedenog problem može biti još veći, upravo iz razloga što postoji mnogo jedinki koje predstavljaju značajne aktere u međunarodnome životu i međunarodnim odnosima, a koje ni po kojoj osnovi nisu pravne osobe u međunarodnopravnom poretku. U ovom smislu, suvremena međunarodna realnost je takva da postoji značajan disparitet između faktičkih i normativnih elemenata međunarodnopravnoga poretka.

svjetskog poretka i osporilo njegovu dimenziju svjetskog. On možda jeste novi, zapadni svakako jeste, ali više se ne može smatrati svjetskim. Iz tog razloga period prvih desetljeća XXI stoljeća neophodno je determinirati kao vrijeme suvremenih tendencija u razvoju međunarodnoga prava, koje će se precizno moći imenovati tek po okončanju danas aktualnih procesa u međunarodnome životu. Šire v. SAVIĆ, M., Međunarodno pravo na početku XXI vijeka - Teorijski pogled na savremenu doktrinu, procese i probleme međunarodnog pravnog poretka, Pravna riječ, br. 44/2015., god. XII. 
Međutim, određenje ovog dispariteta je specifično zato što međunarodnopravni poredak ima vrlo kompleksnu strukturu, pri čemu ga karakterizira izuzetan dinamizam. Sa svim svojim nedostacima (koji, nažalost, često pogađaju u srž) obuhvaća sveukupnost 1) pravila (normi) pozitivnoga međunarodnoga prava koja proizlaze iz svih njegovih izvora, tj. svih ugovora na snazi, 2) svih općih i partikularnih običajnih pravila, 3) općih pravnih načela koja se primjenjuju, 4) međudržavne prakse, tj. postupanja u međunarodnom životu, te 5) relevantnih jednostranih akata država. ${ }^{36}$ Pojednostavljeno možemo reći da međunarodni pravni poredak obuhvaća sve norme međunarodnoga prava, odnose i ponašanje u okviru međunarodne zajednice (država) te opće vrijednosti koje je čovječanstvo, u cijelosti, do danas izgradilo. I on kao takav predstavlja pravni poredak kojemu svi pojedinci, mada posredno, pripadaju. To je istinska sveukupnost međunarodnoga života, čiji glavni akteri su države i međunarodne organizacije, a krajnji adresati su upravo pojedinci. Iako su ti pojedinci pripadnici (državljani) međunarodno priznatih država, oni posjeduju međunarodnopravni subjektivitet u posebnim slučajevima. U skladu sa navedenim, možemo reći da je međunarodnopravni poredak komplementaran sa državnim pravnim porecima, pri čemu oni predstavljaju jedinstvenu cjelinu. Međutim, u toj cjelini države još uvijek zadržavaju svoju autonomiju i tako čine osnovne faktore (organizme, ličnosti) međunarodnopravnoga poretka. ${ }^{37}$ Subjekti ovako shvaćenog međunarodnopravnoga poretka su svi organizmi koji posjeduju opće i posebne sposobnosti u međunarodnome pravu - odnosno mogu biti nosioci prava i obveza u međunarodnopravnim odnosima.

Problem međunarodnopravnoga subjektiviteta je na ovaj način još više produbljen aktualnim pitanjima i izazovima koji se postavljaju pred međunarodnopravni poredak. Status subjekata međunarodnoga prava se dodatno usložnjava, posebno ako uzmemo u obzir i odnos unutarnjega i međunarodnoga prava. Tako se svi pravni subjekti mogu podijeliti na države, subjekte u državama (fizičke i pravne osobe) i subjekte izvan država (druge države, međunarodne organizacije i dr.). Ovako shvaćene osobe mogu biti subjekti unutarnjega (državnog) prava, subjekti međunarodnoga prava, a mogu biti istovremeno subjekti i unutarnjega i međunarodnoga prava. ${ }^{38}$ Nema sumnje da postoje značajne razlike između subjekata međunarodnoga prava, posebno u pogledu njihovog faktičkog statusa.

\footnotetext{
${ }^{36}$ Šire v. DEGAN, V. Đ., Međunarodno pravo, Rijeka, 2000., str. 3.

${ }^{37} \mathrm{O}$ ovome šire v. SAVIĆ, M., Međunarodnopravni poredak i diplomatsko-konzularno pravo - razvojni put međudržavnih odnosa, Banja Luka, 2016., str. 11.

${ }^{38}$ KRIVOKAPIĆ, B., Aktuelni problemi međunarodnog prava, Beograd, 2011., str. 68.
} 


\section{Konkretno određenje subjektiviteta u međunarodnome pravu}

Subjekti međunarodnoga prava su, kako smo već rekli, sve osobe (prije svega pravne, a izuzetno i fizičke) koje mogu biti nositelji prava i obveza u međunarodnopravnom poretku. $\mathrm{Na}$ prvom mjestu to su države i međunarodne organizacije. Međutim, pored ove dvije kategorije, postoje i drugi specifični subjekti međunarodnoga prava. Pored drugih specifičnih podjela, postoje i značajne razlike u pogledu subjektiviteta međunarodnih organizacija koje determiniraju i postojanje, u pravnom smislu, različitih pravnih subjektiviteta i svakako njihovog međunarodnopravnoga statusa. ${ }^{39}$ Sve navedeno potvrđuje činjenicu da je pojam subjekta međunarodnoga prava višeznačan i svakako dinamičan, posebno u pogledu pravne prakse u međunarodnopravnom poretku. Države su originarni subjekti međunarodnoga prava. One su istovremeno njegov glavni zakonodavac i adresat. S tim što ne smijemo zanemariti da do legislative u međunarodnom pravu kakvu danas poznajemo ne bi došlo bez međunarodnih organizacija, prije svega Organizacije Ujedinjenih naroda, što upravo potvrđuje, ne samo njihov subjektivitet, već nam ukazuje na potrebu za konkretnijom regionalnom kooperacijom i integracijom države koja bi onda na osnovu načela koordinacije i supsidijarnosti mogla uvjetovati formiranje jedinstvenog međunarodnopravnoga zakonodavnog tijela, koje bi se tek tada imalo smatrati svjetskim zakonodavcem. Međutim, s obzirom na iskustvo OUN-a i prema aktualnoj realnosti međunarodnoga života, ovo danas predstavlja utopijsku koncepciju.

Kao što smo već ranije naglasili, organizmi koji imaju sposobnost da budu nositelji određenih prava i obveza u međunarodnopravnome poretku mogu se smatrati subjektima međunarodnoga prava. Obično se određuju četiri sposobnosti. ${ }^{40}$ To su: pravna sposobnost koja podrazumijeva mogućnost uživanja prava, te posjedovanje neophodnog kapaciteta za ispunjavanje obveza koje proistječu iz načela i pravila međunarodnoga prava, pri čemu određeni organizam, da bi bio prepoznat kao subjekt međunarodnoga prava a priori navedeno treba da posjeduje; poslovna sposobnost - predstavlja mogućnost stjecanja i raspolaganja pravima, uz mogućnost preuzimanja i ispunjavanja obveza koje konkretni organizam sopstvenim istupanjem u pravnim odnosima dobrovoljno preuzima; procesna sposobnost-koja

\footnotetext{
${ }^{39}$ Međunarodnopravni subjektivitet konkretnih međunarodnih organizacija nije istovjetan i njegov kvalitet se diferencira u različitim slučajevima, odnosno ovisi od specifičnih karakteristika samih organizacija. Tako, međunarodnopravni subjektivitet OUN i Vijeća Evrope se razlikuje (iako ove organizacije dijele gotovo sve konstitutivne elemente). S druge strane, subjektivitet OSCE-a u odnosu na prethodne dvije organizacije se još značajnije razlikuje, a kada ovome dodamo pitanja koja se otvaraju u pogledu međunarodnopravnoga subjektiviteta Evropske unije, dobijamo posebnu dimenziju diferenciranja.

${ }^{40}$ Ovo se na nekim mjestima u literaturi naziva i principom sposobnosti, ili pak načelom četiri sposobnosti.
} 
se ogleda u legitimnosti za pokretanje međunarodnih postupaka pred Međunarodnim sudom pravde u Hagu i drugim međunarodnim sudskim tijelima; deliktna sposobnost - koju možemo odrediti kao mogućnost pozivanja na odgovornost određenog subjekta za kršenje međunarodnih obaveza. ${ }^{41}$ Ove četiri sposobnosti se smatraju općim sposobnostima i one su u formalnom smislu istovjetne sposobnostima koje se određuju subjektima u unutarnjemu pravu. U kontekstu međunarodnopravnog subjektiviteta možemo definirati pravo zaključenja međunarodnih ugovora - ius contrahendi, kao i pravo međunarodnog predstavljanja - ius representationis kao jedinstvo pravne i poslovne sposobnosti, a koje predstavljaju osnovu međunarodnopravnoga subjektiviteta. Zaključenjem međunarodnih ugovora i predstavljanjem u inozemstvu stvaraju se prava i obveze, a koja proizlaze iz volje subjekata međunarodnoga prava. Na ovaj način subjekti međunarodnoga prava posjeduju sposobnost, s jedne strane, da preuzimaju određena prava $\mathrm{i}$ da, $\mathrm{s}$ druge strane, prihvate konkretne obveze sadržane $\mathrm{u}$ međunarondome ugovoru. ${ }^{42}$

Svakako, razlike između unutarnjega (državnog) i međunarodnoga prava predodređuju i značajnu diferencijaciju u pogledu sadržine navedenih sposobnosti, kao što se i unutardržavni i međunarodnopravni odnosi ne mogu istovjetno identificirati. Pored općih sposobnosti, u međunarodnome pravu postoji i veliki broj tzv. posebnih sposobnosti koje u teoriji međunarodnoga prava nisu jedinstveno određene. Neki autori smatraju da ove posebne sposobnosti predstavljaju upravo onu supstancijalnu, odnosno političku komponentu koju kao takvu u smislu subjekata prava odbacuju. S druge strane, postoje autori koji ove sposobnosti definiraju kao sastavni dio pravne, odnosno poslovne sposobnosti. Ipak, ova pitanja je neophodno posebno istaći i definirati ih kao posebne (ostale, dodatne) sposobnosti koje, uz osnovne četiri, predstavljaju dodatne elemente potpunog međunarodnopravnoga subjektiviteta.

S tim u svezi, A. Magarašević naglašava da postoji određeni broj “...dodatnih sposobnosti ili, pak, karakteristika koje posebno određuju međunarodnopravni subjektivitet i koje su jedinstvene samo za subjekte međunarodnog prava. Ovdje je riječ o npr. pravnostvaralačkoj sposobnosti koja podrazumijeva mogućnost učestvovanja u stvaranju, izmjenama ili gašenju pravila međunarodnoga prava, kao i sposobnost, odnosno pravo slanja i primanja diplomatskih misija, te specifičnost pružanja diplomatske zaštite u inozemstvu." ${ }^{43}$ Nadalje, kada je riječ o posebnim karakteristikama, možemo govoriti i o imunitetu

\footnotetext{
${ }^{41}$ Šire v. SAVIĆ, M., cit. dj.

${ }^{42}$ Šire v. SAVIĆ, M., Problemi državnopravnog subjektiviteta u savremenim izazovima međunarodnog prava, dok. dis., Pravni fakultet UNIBL, Banja Luka, 2015., str. 69-73.

${ }^{43}$ MAGARAŠEVIĆ, A., Osnovi međunarodnog prva, Novi Sad, 1965., str. 97.
} 
međunarodnopravnoga subjekta od nacionalne jurisdikcije, kao i o sudskom imunitetu u širem smislu koji podrazumijeva da se subjekt međunarodnog prava u postupku pred bilo kojim sudom može pojaviti samo na osnovu dobrovoljnosti, što predstavlja njegovu posebnu sposobnost. ${ }^{44}$ Takođe, R. Portman naglašava jedinstvenost subjekata međunarodnoga prava $u$ pogledu sposobnosti stvaranja međunarodnopravnih pravila, ali i sposobnosti za ograničenje primjene određenih pravila. ${ }^{45}$ Posebne sposobnosti kao dodatne elemente međunarodnopravnoga subjektiviteta u najširem smislu možemo odrediti, kako je to uradio B. Krivokapić, kao ostale sposobnosti subjekata međunarodnog prava, a koje podrazumijevaju: 1) aktivno i pasivno pravo poslanstva, tj. sposobnost da se šalju i primaju diplomatski zastupnici; 2) sposobnost da se sudjeluje u radu međunarodnih konferencija; 3) sposobnost da se bude član međunarodnih organizacija; 4) sposobnost vođenja obrambenog rata i preuzimanja prinudnih mjera; 5) sposobnost mirnog rješavanja sporova, odnosno učešća u tim procesima; 6) sposobnost da se uživa imunitet od strane jurisdikcije. ${ }^{46}$

\section{Zaključak}

Na temelju svega prethodno navedenog može se izvesti zaključak da je pojam subjekta međunarodnoga prava višeznačan i svakako dinamičan, što posebno dobija na značaju u okolnostima suvremenih izazova koji se postavljaju unutar međunarodnopravnoga poretka. S tim u svezi, subjekte međunarodnog prava - organizme koji posjeduju potpuni ili, pak, ograničeni, djelomični međunarodnopravni subjektivitet danas možemo klasificirati u okviru pet općih kategorija.

1) države koje bez dileme predstavljaju osnovne subjekte međunarodnoga prava i koje danas u suvremenom svijetu posjeduju, ipak diferencijalno prema posebnom kvalitetu, ekskluzivitet formalnopravne suverene nezavisnosti;

2) subjekte slične državama (kvazi-države) koji u kontekstu suvremenog međunarodnoga prava na početku XXI stoljeća obuhvaćaju a) zavisne pravne osobe slične državama kao organizme koji posjeduju gotovo sve atribute kao i suverene države, ali to nisu, ${ }^{47}$

\footnotetext{
${ }^{44}$ BROWNLIE, I., Principles of Public International Law, IV Edition, Oxford University Press, 1990., str. 60.

${ }^{45}$ PORTMANN, R., cit. dj. str. 8., 69., 231-312.

${ }^{46}$ KRIVOKAPIĆ, B., cit., dj. str. 69.

${ }^{47}$ Prema prethodno navedenoj strukturi možemo izvršiti klasifikaciju zavisnih pravnih osoba na osnovu njihove pravne prirode, povijesnih okolnosti, načina uspostavljanja, općeg karaktera, obima državnopravnog subjektiviteta i dr. Zavisne pravne osobe su: 1) vazalne države, 2) protektorati i 3) neoprotektorati, uz poseban položaj državotvornih organizama, koji od slučaja do slučaja mogu imati elemente i zavisnih pravnih osoba, odnosno mogu
} 
b) državotvorne organizme ${ }^{48}$ koji se tek trebaju uspostaviti kao (potpune) pravne osobe u međunarodnome pravu, pri čemu trenutno posjeduju usko određen i ograničen međunarodnopravni subjektivitet i c) nesamostalne teritorije pod posebnim mandatom, a koje mogu posjedovati elemente subjektiviteta u međunarodnome pravu i mogu se ponovo u drugom obliku pojaviti u skoroj budućnosti. ${ }^{49}$ U XXI stoljeću zavisne pravne osobe zavrijeđuju posebnu pažnju jer će, kako nam praksa pokazuje u godinama koje dolaze, biti, mada u različitim oblicima, čest fenomen s kojim će se međunarodno pravo morati suočiti.

3) međunarodne organizacije kao subjekte koji su stvoreni od strane država i koji danas istovremeno predstavljaju formalne međunarodne institucije (organe), osnovu opće međunarodne koordinacije, institucionalizirani okvir međudržavne i opće svjetske - globalne saradnje. Ovdje mislimo na međunarodne organizacije javnog karaktera, tj. međunarodne institucije formirane od strane država.

4) transnacionalne organizacije i udruženja koja predstavljaju posebne subjekte međunarodnoga prava formirane od strane nedržavnih subjekata. Ovi organizmi čiji osnivači nisu države zauzimaju sve značajnije mjesto u međunarodnopravnom poretku - točnije imaju sve više utjecaja u pogledu njegovih elemenata. Na prvom mjestu, kao transnacionalne organizacije možemo odrediti međunarodne nevladine organizacije koje zauzimaju posebno mjesto u međunarodnopravnom poretku, bez jedinstvenog formalnopravnog okvira koji se može primijetiti kod međunarodnih javnih organizacija. Međutim, one kao takve predstavljaju posebne subjekte međunarodnoga prava. Nevladine organizacije ne predstavljaju homogen korpus subjekata. Neke su sastavljene od malog broja privilegovane elite koja djeluje iza scene, kao npr. Bilderberg grupa (Bilderberg Group) i Trilateralna komisija (Tirlateral Commission), druge su opet masovne i vidljive i svoju djelatnost ispoljavaju otvoreno u cilju razmjene informacija ili pokretanja zajedničke akcije - Transparensi internašonal (Transparency International). Neke su strukovne i profilisane, kao FIFA, FIBA, IHF i dr. Velike razlike postoje u obimu i strukturi članstva i načinu funkcionisanja. ${ }^{50}$ Heterogenost nevladinih

posjedovati kvalitete pravne osobe u međunarodnome pravu. Prve dvije kategorije predstavljaju tekovinu prošlosti i danas ne postoje. Šire v. ibid.

${ }^{48}$ Državotvorni organizmi su (pravne osobe) države u nastajanju, na čijim teritorijama se odvija proces uspostavljanja vlasti. U ovu kategoriju možemo svrstati i neke teritorije koje su bile pod međunarodnim mandatom u prošlosti, a koje su organizirale određeni stupanj samostalne vlasti, na osnovu čega su prije specialis subjekti, nego objekti u međunarodnome pravu.

${ }^{49}$ Danas je posebno značajan međunarodnopravni subjektivitet neoprotektorata kao posebnog oblika zavisne pravne osobe, prije svega zato što analizom ovog fenomena možemo primjetiti mnoge specifičnosti suvremenih izazova međunarodnog prava. O ovome, šire v. SAVIĆ, M., Bosna i Hercegovina - država ili neoprotektorat?, Dejtonski sporazum, dve decenije mira i pouke za svet, Beograd, 2016., str. 173-191.

${ }^{50} \mathrm{Ibid}$, str. 173. 
organizacija predstavlja osnovnu teškoću u iznalaženju jedne precizne definicije koja bi mogla objediniti ovaj veoma brojan korpus organizacija kao subjekata međunarodnoga prava.

$\mathrm{Na}$ drugom mjestu se nalaze multinacionalne - transnacionalne kompanije (preduzeća, privredna društva, korporacije i sl.) čija uloga i značaj su u stalnom porastu. Ove kompanije se još nazivaju i globalnim korporacijama, što se može podvesti pod pojam gospodarskih subjekata, a koje u cilju postizanja što većeg profita djeluju i imaju ogranke u više država. ${ }^{51}$

5) pojedinac koji se sve češće javlja kao neposredni nositelj određenih prava i obveza u međunarodnome pravu. Njegova prava, odnosno pravne ovlasti u konkretnom pravnom odnosu pronalazi utemeljenje u međunarodnome pravu ljudskih prava, dok se on, s druge strane, može pozvati neposredno na odgovornost u skladu sa normama međunarodnog kaznenog prava. $U$ skladu sa navedenim, pojedinac danas posjeduje pravnu sposobnost koja je, ipak, u velikoj mjeri ograničena. Međutim, širi okvir međunarodnopravnog subjektiviteta on uživa u pogledu procesne, ali i deliktne sposobnosti.

\section{CURRENT ISSUES OF INTERNATIONAL LEGAL PERSONALITY}

Summary: In this paper, the author deals with current theoretical issues of international legal personality. The author analyzes the most important understandings and concepts in the theory of international law, which have an impact on the contemporary international legal trends. International law is changed, the international legal order, with all the problems is intensively developing which directly affects the changes in terms of defining the subjects of international law today. The international legal relations are extremely complex and today, there are more different - specific holders of rights and obligations in these relationships. Entities (organisms, personalities) participating in international legal relations are increasingly differ (from one another) in terms of status, scope of subjectivity, general and specific legitimation, specific capacities, etc.. The theory of international law today is facing major problems regarding the definition of subjects of international law, which is one of the main issues discussed in this paper.

\footnotetext{
${ }^{51}$ Danas najpoznatije multinacionalne kompanije predstavljaju korporacije kao što su: Ford Motor Company, IBM, Exxon Mobil, Siemens, Heineken, Honda, Nestle, Samsung, Nike, Boeing, General Motors, Coca Cola itd. Šire v. isto.
} 
Keywords: Subjects of law, International personality, International legal relations, Voluntarism, Objectivism, Legal positivism, Capacities, Rights and obligations. 